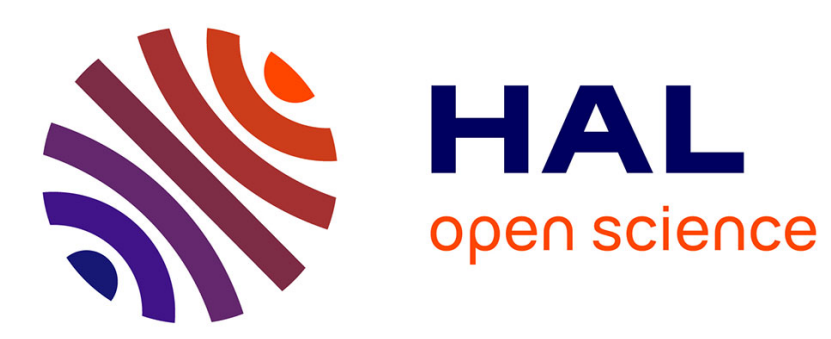

\title{
Effective Tools for the Metal-catalyzed Regiodivergent Direct Arylations of (Hetero)arenes
}

\author{
Hai-Yun Huang, Amal Benzai, Xinzhe Shi, Henri Doucet
}

\section{To cite this version:}

Hai-Yun Huang, Amal Benzai, Xinzhe Shi, Henri Doucet. Effective Tools for the Metal-catalyzed Regiodivergent Direct Arylations of (Hetero)arenes. Chemical Record, 2021, 21 (2), pp.343-356. 10.1002/tcr.202000145 . hal-03100367

\section{HAL Id: hal-03100367 https://hal.science/hal-03100367}

Submitted on 16 Feb 2021

HAL is a multi-disciplinary open access archive for the deposit and dissemination of scientific research documents, whether they are published or not. The documents may come from teaching and research institutions in France or abroad, or from public or private research centers.
L'archive ouverte pluridisciplinaire HAL, est destinée au dépôt et à la diffusion de documents scientifiques de niveau recherche, publiés ou non, émanant des établissements d'enseignement et de recherche français ou étrangers, des laboratoires publics ou privés. 
Effective tools for the metalcatalyzed regiodivergent direct arylations of (hetero)arenes

Hai-Yun Huang, ${ }^{\text {a] }}$ Amal Benzai, ${ }^{[a]}$ Xinzhe Shi, ${ }^{[a]}$ and Henri Doucet ${ }^{\star}[\mathrm{a}]$

\section{Regiodivergent direct arylations}<smiles></smiles>

$\mathrm{H}$
$\frac{[\mathrm{Pd}]}{\mathrm{Ar} \stackrel{\mathrm{X}, \mathrm{Cs}_{2} \mathrm{CO}_{3}}{ }}$<smiles></smiles><smiles>c1ccccc1</smiles>

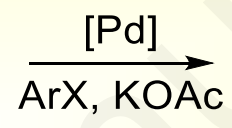<smiles></smiles>

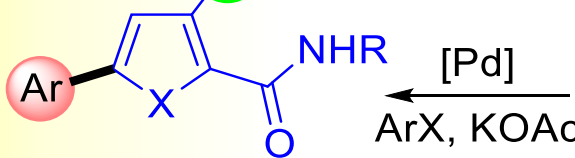<smiles>[X]c1ccccc1Br</smiles><smiles>COC(=O)C(C)(C)C</smiles><smiles>[R]NC(=O)c1[X]c(-c2ccccc2)cc1</smiles>

H<smiles>[X]c1ccccc1C</smiles>

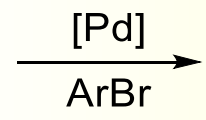<smiles>[R]NC(=O)c1[X]c([Hg])cc1</smiles>

H

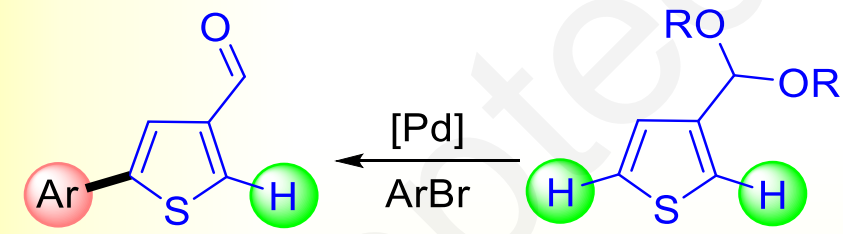<smiles>CC(Br)(Br)Oc1sc(-c2ccccc2)cc1C=O</smiles><smiles>O=Cc1cc(-c2ccccc2)sc1Br</smiles><smiles>[X]c1ccc(-c2ccc(Br)c(Br)c2)cc1[R]</smiles><smiles>[R]c1cc([Hg])c(-c2ccc(C(Br)(Br)Br)cc2)cc1[X]</smiles><smiles>Brc1ccccc1-c1ncco1</smiles><smiles>c1ccc(-c2ncco2)cc1</smiles> 
Abstract: The direct functionalization of tw o different $\mathrm{C}-\mathrm{H}$ bonds of the same organic molecule using different procedures - also called regiodivergent $\mathrm{C}-\mathrm{H}$ bond functionalization - currently represents an important research topic in organic chemistry, as it demonstrates the versatility of $\mathrm{C}-\mathrm{H}$ bond functionalization methodology. Over the last decade, the number of tools to control such regiodivergent $\mathrm{C}-\mathrm{H}$ bond functionalizations has increased significantly. In this account, we will present the various tools that allowed us to arylate different positions of various (hetero)arenes, via a $\mathrm{C}-\mathrm{H}$ bond functionalization, using palladium or ruthenium catalysis.

\section{Introduction}

When specific $\mathrm{C}-\mathrm{H}$ bonds of organic molecules such as arenes or heteroarenes can be directly functionalized via catalytic reactions, it provides straightforw ard methods for the synthesis of (hetero)aromatic derivatives. Since the first reports in 1982 by Nakamura, Tajima and Sakai and in 1985 by Ohta et al. on the arylation of heteroarenes, and the reports by $\mathrm{Oi}$, Inoue et al. in 2001 and Fagnou et al. in 2006 on the arylation of 2arylpyridines, 2-arylazoles, polyfluorobenzenes and pyridines, the metal-catalyzed so called "direct arylation" via the $\mathrm{C}-\mathrm{H}$ bond functionalization of 5- and 6-membered ring (hetero)aromatics with aryl (pseudo)halides, has emerged as one of the most pow erful methods allow ing a simple access to (hetero)biaryls. ${ }^{[1-3]}$ The chief advantages of such protocol is that 1) the major byproduct is $\mathrm{HX}$ associated to a base instead of metallic or boron salts with classical coupling procedures, and 2) no prior preparation of organometallics such as organozinc or boron derivatives is required, reducing the number of synthesis steps.

Initially, in most cases, only the "most reactive" $\mathrm{C}$ - $\mathrm{H}$ bond of (hetero)arenes could be functionalized. ${ }^{[1]}$ How ever, C-H bond functionalization will be really synthetically useful for pharmaceutical or organic material chemists when it will be possible to activate a specific $\mathrm{C}-\mathrm{H}$ bond on molecules. Therefore, the discovery of conditions allow ing the regioselective functionalization of several $\mathrm{C}-\mathrm{H}$ bonds of the same molecule, also called regiodivergent functionalization, is a very important aspect of the current researches dealing $w$ ith metal-catalyzed C$\mathrm{H}$ bond arylation.

Since tw o decades, several tools have been discovered allow ing to functionalize more than one $\mathrm{C}-\mathrm{H}$ bond of the same (or very similar) (hetero)arenes giving rise to different bi(hetero)aryls. For example, such regiodivergent functionalizations are possible by 1) the use of specific base/solvent systems, 2) the activation of directing groups, 3) changing the nature of the aryl source, 4) exploiting the steric hindrance of one of the coupling partners, 5) the use of blocking groups, and 6) changing the metal catalyst (Fig 1). In this account, we will summarize our results dealing with the functionalization of two different $\mathrm{C}-\mathrm{H}$ bonds of various (hetero)arenes based on these six tools.

1) Specific base/solvent systems

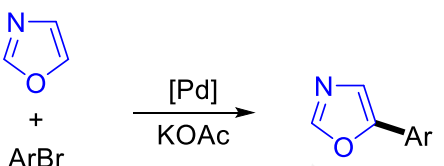

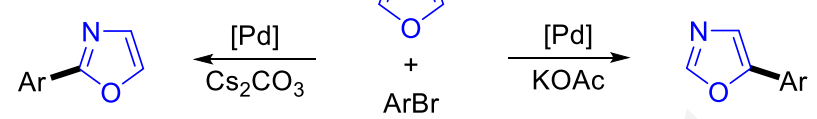

2) Activation of directing groups

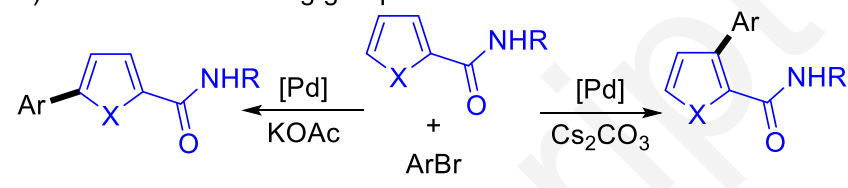

3) Nature of the aryl source

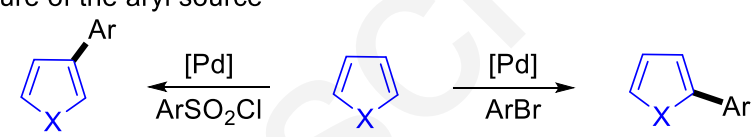

4) Steric hindrance

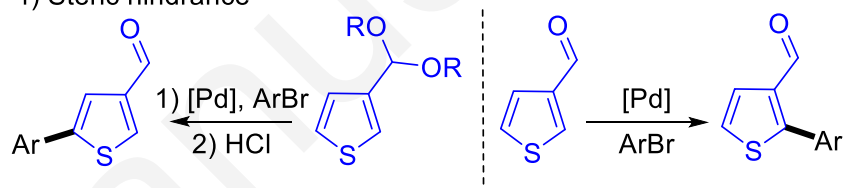

5) Blocking groups

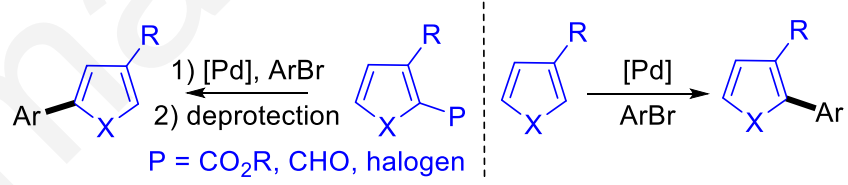

6) Nature of the metal of catalyst

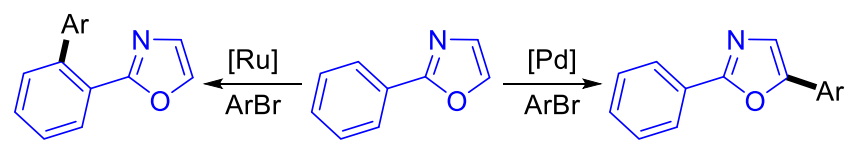

Figure 1. Tools for the regiodiv ergent metal-cataly zed direct ary lations.

Hai-Yun Huang was born in P.R. China. She joined the international master's program "Cataly sis, Molecules and Green Chemistry" in the Univ ersity of Rennes 1 (France) in 2016. She performed her master's research training in Dr. C. Fischmeister's team in the Univ ersity of Rennes 1 . She currently works towards a PhD degree of Univ ersity of Rennes 1 under the supervision of Dr. Henri Doucet and Dr. Jean-François Soulé. She

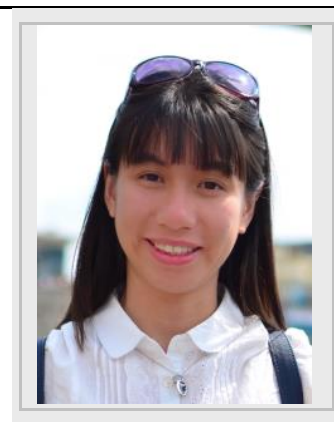
receiv ed a grant from the China Scholarship Council (CSC) in 2018. Her work focuses on the $\mathrm{C}-\mathrm{H}$ bond functionalization using palladium cataly sis

[a] Ms H.-Y. Huang, Ms A. Benzai, Dr. X. Shi, Dr. H. Doucet CNRS, ISCR-UMR 6226

Univ Rennes

F-35000 Rennes, France

E-mail: henri.doucet@univ -rennes1.fr 
Amal Benzai was born in Algeria. She currently works towards a PhD degree of University of Rennes 1 and Univ ersity of Mouloud Mammeri Tizi-Ouzou (UMMTO), Algeria under the supervision of Pr. Fazia Derridj, Dr. Henri Doucet and Dr. JeanAlgerian Government in 2018. Her work focuses on the $\mathrm{C}-\mathrm{H}$ bond functionalization using palladium cataly sis.

Xinzhe Shi was born in P.R. China. She joined the international master's program "Cataly sis, Molecules and Green Chemistry" in the Univ ersity of Rennes 1 (France) receiv ing grants from the Foundation Rennes 1 in 2015. She performed her master's research training in H. Doucet and J. F. Soulé team. She receiv ed her $\mathrm{PhD}$ degree of Univ ersity of Rennes 1 working the supervision of Dr. Henri Doucet and Dr. Jean-François Soulé in 2020. Her work focused on the $\mathrm{C}-\mathrm{H}$ bond functionalization using palladium cataly sis

Henri Doucet receiv ed his PhD in chemistry 1994. Af ter post-doctoral appointments at Oxford univ ersity (UK) with Prof. J. M. Brown; and Nagoy a univ ersity, (Japan) with Prof. R. Noy ori, he moved to the Univ ersity of Marseille (France) as CNRS researcher in the group of Prof M. Santelli. In 2006 he moved to Rennes 1 Univ ersity. His research interests include organic synthesis by metal-cataly zed processes and green chemistry.
François Soulé. She receiv ed a grant from the working with Prof. P. H. Dixneuf and Dr. C Bruneau at Rennes 1 Univ ersity (France) in
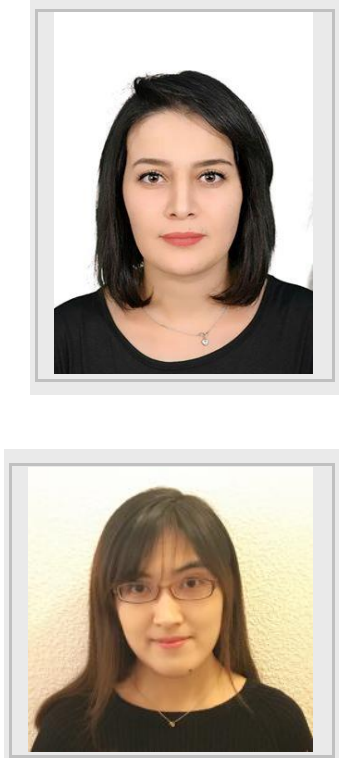

However, the free energy of activation for Pd-catalyzed direct arylation of oxazole via Concerted Metalation Deprotonation (CMD) pathway (Scheme 1) which has been calculated by Gorelsky ${ }^{[6]}$ reveals that it is higher for the $\mathrm{C}-\mathrm{H}$ bond flanked by two heteroelements $\left(25.3 \mathrm{kcal} \mathrm{mol}^{-1}\right)$ than for the $\mathrm{C}-\mathrm{H}$ bond at C5-position $\left(23.5 \mathrm{kcal} \mathrm{mol}^{-1}\right)$. Ther efore, we expected to be able to control the regioselectivity of the arylation of oxazole in favor of C5-arylation using acetates as base/ligand (CMD pathway); whereas C2-arylations were expected via the deprotonation of the more acidic C2-position of oxazole using stronger bases.

Indeed, in 2019 w e reported that the regioselectivity of the direct arylation of oxazole can be controlled using the appropriate base. ${ }^{[7]}$ From phosphine-free $\mathrm{Pd}(\mathrm{OAc})_{2}$ catalyst associated to $\mathrm{KOAC}$, regioselective C5-arylations, which likely proceed via a CMD mechanis $\mathrm{m}$, were observed (Scheme 1, a). By contrast, the $\mathrm{Pd}(\mathrm{acac})_{2}$ catalyst associated to $\mathrm{Cs}_{2} \mathrm{CO}_{3}$ as the base led regioselectively to the $\mathrm{C} 2$-arylated oxazoles probably via a basedeprotonation of oxazole (Scheme 1, b). A wide variety of (hetero)aryl bromides was tolerated by these two sets of conditions.

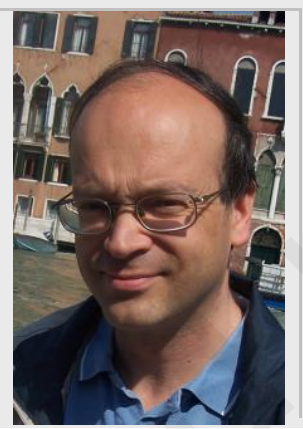

\section{Nature of the base or solvent}

The nature of the base in the $\mathrm{C}-\mathrm{H}$ bond cleavage step is very important. ${ }^{[1]}$ In several cases, a quite strong base may directly deprotonate the substrate; while a weaker base may play the dual role of base and ligand in the metal-assisted $\mathrm{C}-\mathrm{H}$ bond cleavage step. ${ }^{[4]}$ Therefore, with specific substrates, two different $\mathrm{C}-\mathrm{H}$ bonds could be functionalized by changing only the base or the base/solvent combination.

\subsection{Carbonates and acetates}

In 2010, Strotman, Chobanian et al. reported conditions for the regiodivergent $\mathrm{Pd}$-catalyzed direct arylation of oxazoles (C2- vs C5-arylations). ${ }^{[5]}$ They found that the C5-arylation is preferred in DMA associated to $10 \mathrm{~mol} \%$ 2-di-tert-buty lphosphino-3,4,5,6tetramethyl-2', 4',6'-triisopropyl-1, 1'-biphenyl as ligand; whereas, C2-arylation regioselectively took place in xylene associated to 10 mol\% 2-dicyclohexylphosphino-2',6'-diisopropoxybiphenyl ligand. In both cases, $\mathrm{K}_{2} \mathrm{CO}_{3} / \mathrm{PivOH}$ was employed as base/additive, and the regioselectivity $\mathrm{w}$ as controlled by changing the ligand/solvent system. a)

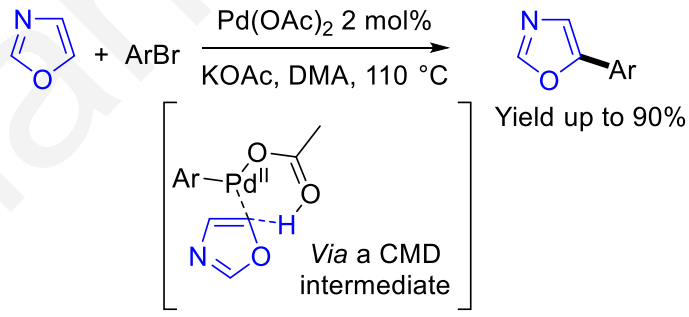

b)

$$
\begin{aligned}
& \underset{\mathrm{O}}{\stackrel{\mathrm{N}}{\|}-\mathrm{ArBr}} \frac{\mathrm{Pd}(\mathrm{acac})_{2} 5 \mathrm{~mol} \%}{\mathrm{Cs}_{2} \mathrm{CO}_{3}, \mathrm{DMA}, 110^{\circ} \mathrm{C}}
\end{aligned}
$$

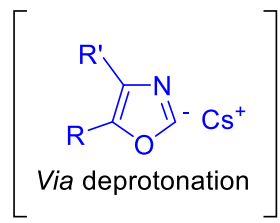

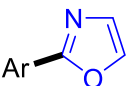

Yield up to $70 \%$

Scheme 1. Conditions for regiodivergent $\mathrm{Pd}$-catalyzed direct anylations of oxazole. pigments in the lactarius indigo mushrooms. As guaiazulene does not contain any reactive function, its modification via catalyzed $\mathrm{C}-\mathrm{H}$ bond functionalization is a very appealing tool. A few years ago, we demonstrated that both the $\mathrm{sp}^{2}$ and $\mathrm{sp}^{3}$ direct arylations of guaiazulene were possible when appropriate reaction conditions were employed. ${ }^{[8]}$ The use of KOAc in ethylbenzene led to the C2-arylated guaiazulenes a (Scheme 2, a); w hereas a mixture of $\mathrm{CsOAc} / \mathrm{K}_{2} \mathrm{CO}_{3}$ selectively promoted the $\mathrm{sp}^{3}$ direct arylation at C4-Me to give 4-benzylguaiazulenes c (Scheme 2, b). The formation of 4-benzylguaiazulenes c might arise from the formation of an allyl-palladium inter mediate such A. The higher base concentration in solution due to the better solubility of Cs OAc compared to KOAc might favor this reaction pathw ay.
Guaiazulene that feature the azulene skeleton is a constituent of 
a)<smiles>Cc1ccc(C(C)C)cc2c(C)ccc1-2</smiles>
$\operatorname{PdCl}\left(\mathrm{C}_{3} \mathrm{H}_{5}\right)(\mathrm{dppb})$
$2 \mathrm{~mol} \%$

$\mathrm{KOAc}$, ethylbenzene $150^{\circ} \mathrm{C}$

$\mathrm{ArBr}$

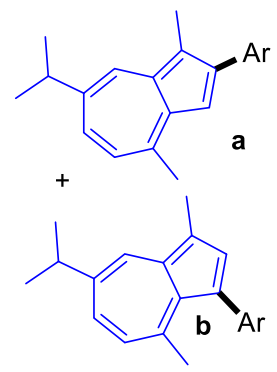

Ratio a:b up to $77: 23$ Yield in a up to $56 \%$ b)

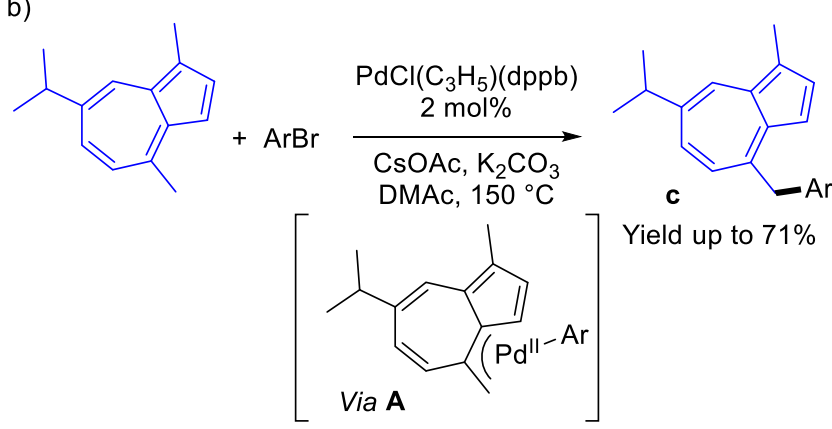

Scheme 2. Conditions for regiodivergent Pd-catalyzed direct arylations of guaiazulene.

\subsection{AgOAc/TFA vs PivOK/NMP}

In 2008, Wu et al. reported that the arylations of 2phenylbenzoxazoles, via a $\mathrm{C}-\mathrm{H}$ bond activation, using $\mathrm{AgOAc} / \mathrm{TFA}$ and $\mathrm{Pd}(\mathrm{OAc})_{2}$ as reaction conditions took place preferentially at the ortho-position of the phenyl ring, due to a directing effect of the nitrogen atom of the benzoxazolyl unit (Scheme 3, a)..$^{[9]}$

In 2016, we reinvestigated the $\mathrm{Pd}$-catalyzed direct arylation of 2arylbenzoxazoles. ${ }^{[10]}$ We found that the use of PivOK as the base in wet NMP instead of AgOAc/TFA, using $\mathrm{PdCl}_{2}$ as the catalyst source allowed the regioselective arylation of 2arylbenzoxazoles at the unexpected C7-position (Scheme 3, b). Mechanistic studies suggest that, under these conditions, the formation of an open form of benzoxazole is the key factor for the control of the regioselectivity, with a coordination of the phenoxy group to palladium (see intermediate in the scheme 3 , b) follow ed by reductive elimination.

a)<smiles>[R]c1cccc(Br)c1-c1nc2ccccc2o1</smiles>

b)

Yield up to $95 \%$

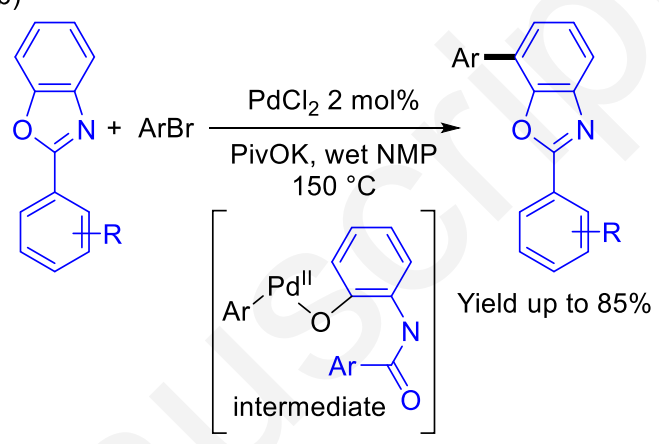

Scheme 3. Conditions for regiodiv ergent $\mathrm{Pd}$-cataly zed direct ary lations of 2ary lbenzoxazoles.

\section{On/off directing groups}

Some specific functional groups can be activated using appropriate reaction conditions to control the site-selectivity of the arylation. For example, a secondary carboxanilide function can be deprotonated with quite strong bases favoring its coordination to palladium resulting in the modification of the regioselectivity of the reaction.

The first example of $\mathrm{C} 3$-arylation of a thiophene derivative substituted at C2-position by a carboxanilide function was reported by Miura et al., using phenyltriflate as the aryl source. ${ }^{[11]}$ Then, the regiodivergent arylation at either the C3- or C5-positions of furans and thiophenes containing secondary carboxamides at C2-position was described by our group. ${ }^{[12]}$ The nature of the base proved to be crucial for the regiocontrol of the arylation. The direct arylation occurred regioselectively at the C5-position in the presence of KOAc; whereas the use of $\mathrm{Cs}_{2} \mathrm{CO}_{3}$ base with xylene solvent regioselectively provided the C3-arylated furans and thiophenes (Scheme 4). The regioselectivity of the arylation also depends on the carboxanilide function, as with tertiary amides only the C5arylated products w ere obtained $w$ hatever the base. 
<smiles>O=C(NI)c1ccc[Y]1(Br)Br</smiles>

$$
\begin{gathered}
\mathrm{PdCl}\left(\mathrm{C}_{3} \mathrm{H}_{5}\right)(\mathrm{dppb}) \\
2 \mathrm{~mol} \% \\
\text { xylene, } \mathrm{Cs}_{2} \mathrm{CO}_{3} \\
150{ }^{\circ} \mathrm{C}
\end{gathered}
$$

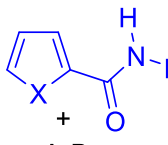

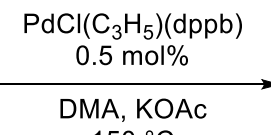
$150{ }^{\circ} \mathrm{C}$

$X=O$ or $S$

Scheme 4. Regiodivergent arylations of furans and thiophenes bearing secondary carboxamides.

The formation of the C3-arylated heteroarenes in the presence of $\mathrm{Cs}_{2} \mathrm{CO}_{3}$ base likely comes from a coordination-assisted mechanis $\mathrm{m}$ via amide deprotonation by the base followed by migration of the palladium at C3-position of the thiophene or furan rings (Scheme 5). Conversely, the C5-arylation observed w ith KOAc probably proceeds via a CMD mechanis $\mathrm{m}$ (Scheme $6)$.

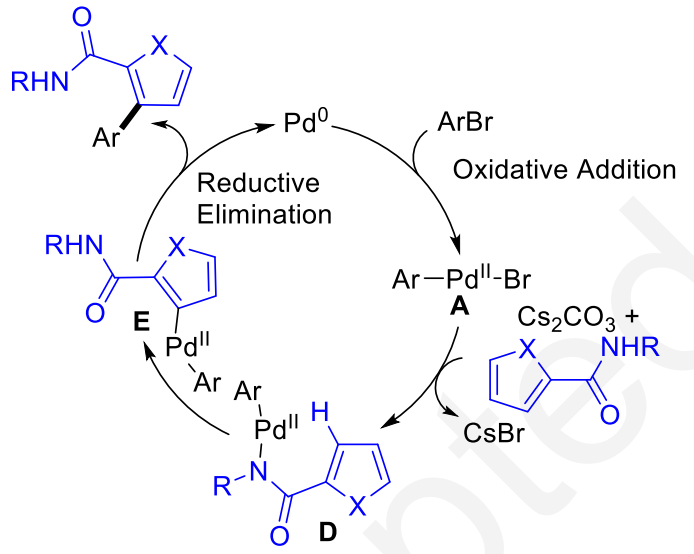

Via amide deprotonation

Scheme 5. Plausible mechanism for $\mathrm{C} 3$-ary lation.

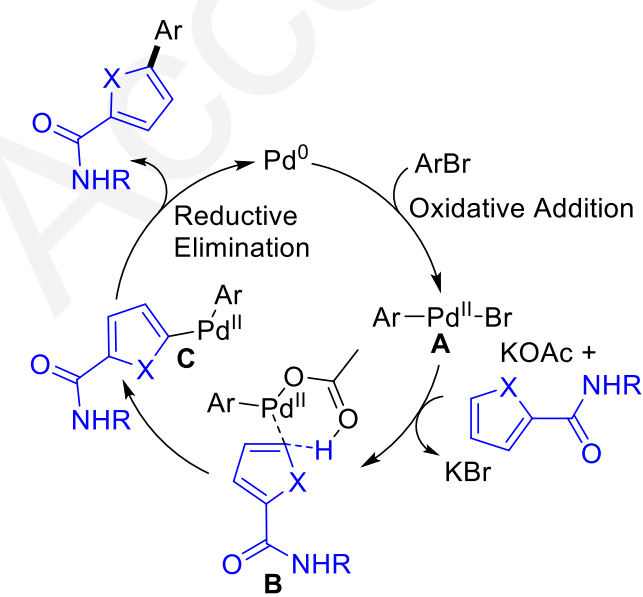

Via Concerted Metallation Deprotonation (CMD)

\section{Aryl source}

With some heteroarenes, the use of alternative aryl sources to aryl halides as the coupling partners allowed to obtain other regioisomers. This strategy has been used by some groups including ours for the arylation of (benzo)thiophenes and selenophenes.

\subsection{Regiodivergent arylations of thiophenes}

The Pd-catalyzed direct arylation of thiophenes with aryl halides generally occurs regioselectively at C2- or C5-positions ( $\alpha$ arylations) (Scheme $7, a) \cdot{ }^{[13]}$ How ever, a few groups succeeded to obtain C3- or C4-arylated ( $\beta$-arylated) thiophenes using other aryl sources. In 2011, Studer, Itami et al. developed a method for the $\beta$-arylations of thiophenes using arylboronic acids as the aryl source under Pd/TEMPO catalysis (Scheme 7, b).$^{[14]}$ Then, in 2012 Oi et al. reported a procedure for the $\beta$-arylation of thiophenes using aryltrimethylsilanes as the coupling partners in the presence of $\mathrm{PdCl}_{2}(\mathrm{MeCN})_{2}$ catalyst with $\mathrm{CuCl}_{2}$ as oxidant (Scheme 7, c). ${ }^{[15]}$ Glorius et al. also reported conditions allowing the $\beta$-arylation of thiophenes using aryliodonium salts as the aryl source and $\mathrm{Pd} / \mathrm{C}$ catalyst. ${ }^{[16 a]} \mathrm{A}$ room temperature procedure for the $\beta$-arylation of thiophenes using aryl iodides, $\mathrm{Ag}_{2} \mathrm{CO}_{3}$ base in $1,1,1,3,3,3$-hexafluoroisopropan-2-ol has also been reported by Larrosa et al. in 2016. ${ }^{[16 \mathrm{~b}]}$

In 2014, our group investigated the reactivity of benzenesulfonyl chlorides as the aryl source for the arylation of thiophenes (Scheme 7, d). ${ }^{[17 a]} \mathrm{PdCl}_{2}(\mathrm{MeCN})_{2}$ or $\mathrm{Pd}(\mathrm{OAc})_{2}$ catalysts in the presence of 3 equivalents of $\mathrm{Li}_{2} \mathrm{CO}_{3}$ as base in 1,4-dioxane without additives or ligands regioselectively provided the $\beta$ arylated thiophenes in high yields. It should be mentioned that the reaction tolerated chloro-, bromo- and iodo-substituents on the benzenesulfonyl chlorides. ${ }^{[17 \mathrm{a}, 17 \mathrm{~b}]}$ Moreover, these desulfitative cross-couplings could be performed in diethylcarbonate or cyclopentyl methyl ether as green and renewable solvents or even in neat conditions. ${ }^{[17 c]}$ We also recently successfully employed heterogeneous $10 \% \quad \mathrm{Pd} / \mathrm{C}$ catalyst for the direct $\beta$-arylation of thiophene derivatives $w$ ith a range of benzenesulfonyl chlorides. These couplings likely proceed via the formation of homogeneous catalytically active soluble clusters or nanoparticles from $\mathrm{Pd} / \mathrm{C}^{\left[{ }^{[17 d]}\right.}$ The regioselectivities $w$ ith $\mathrm{Pd} / \mathrm{C}$ catalyst were similar to those observed $w$ ith the homogeneous palladium catalysts $\operatorname{Pd}(O A c)_{2}$ or $\mathrm{PdCl}_{2}(\mathrm{MeCN})_{2}$ when benzenesulfonyl chlorides were employed as the aryl sources. Due to the very wide availability of diversely functionalized benzenesulfonyl chlorides, these aryl sources should be very attractive to organic chemists for access to $\beta$-arylthiophenes. For these desulfitative couplings, albeit no mechanistic investigation has been performed, we have suggested a mechanism pathway, based on a $\mathrm{Pd}(\mathrm{II}) / \mathrm{Pd}(\mathrm{IV})$ catalytic system, as it is know $n$ that benzenesulfonyl chlorides can transform $\mathrm{Pd}(\mathrm{II})$ into $\mathrm{Pd}(\mathrm{IV})$ by oxidative addition even at room temperature. ${ }^{[17 \mathrm{e}]}$

We applied this methodology to the synthesis of polyaromatic hydrocarbon containing a sulfur atom (Scheme 7, e). ${ }^{[17 f]}$ The 
strategy involved a Pd-catalyzed desulfitative regioselective C4arylation of thiophenes with 2-bromobenzenesulfonyl chlorides followed by a Pd-promoted one-pot cascade $\mathrm{C}$ - $\mathrm{H}$ bond direct C5-arylation of the thiophene ring followed by a cyclization reaction. A wide range of diversely substituted thio-containing polyaromatic hydrocarbon $w$ as synthesized in high yields by this method.

a)

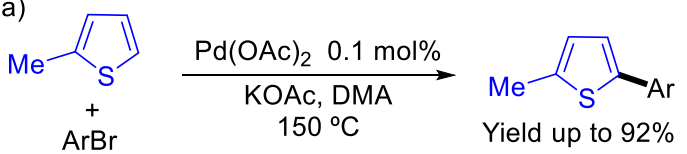

b)<smiles>[R]c1ccsc1[18F]</smiles>

$$
\begin{gathered}
\mathrm{Pd}(\mathrm{OAc})_{2} 10 \mathrm{~mol} \% \\
\text { bipy } 10 \mathrm{~mol} \%
\end{gathered}
$$
$\operatorname{ArB}(\mathrm{OH})_{2}$

c)<smiles>[R]c1ccsc1[18F]</smiles>

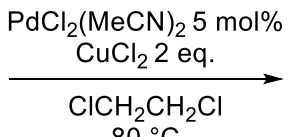
$80^{\circ} \mathrm{C}$

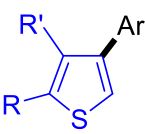

Yield up to $97 \%$ $\mathrm{ArSiMe}_{3}$

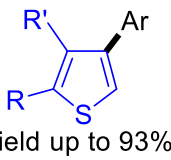
Yield up to $93 \%$

d)<smiles>[R]c1cccs1</smiles>
$\underset{\substack{\mathrm{Li}_{2} \mathrm{CO}_{3}, \text { solvent } \\ 140^{\circ} \mathrm{C}}}{\stackrel{\mathrm{PdCl}_{2}(\mathrm{MeCN})_{2} 5 \mathrm{~mol} \%}{\longrightarrow}}$ $140^{\circ} \mathrm{C}$

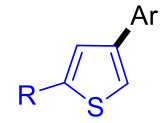

Yield up to $88 \%$ Solvent $=1,4$-dioxane, diethyl carbonate, cyclopentyl methyl ether, neat

$$
\text { e) }
$$<smiles>[R]C1=CCCS1</smiles>

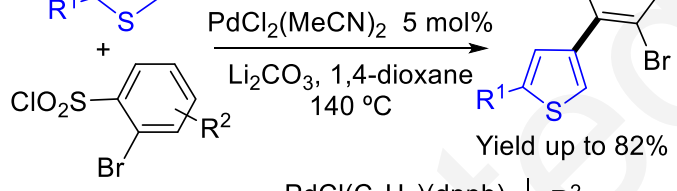

$\mathrm{PdCl}\left(\mathrm{C}_{3} \mathrm{H}_{5}\right)(\mathrm{dppb})$ $2 \mathrm{~mol} \%, \mathrm{ArBr}, \mathrm{KOA}$ DMA, $150^{\circ} \mathrm{C}$

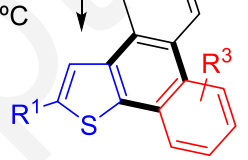

Yield up to $90 \%$

Scheme 7. Selected examples of regiodiv ergent ary lations of thiophenes.

\subsection{Regiodivergent arylations of benzothiophenes}

The reactivity of benzothiophenes is quite similar to thiophenes, and they can be regioselectively arylated by aryl bromides at their C2-position ( $\alpha$-arylation) using $\operatorname{Pd}(\mathrm{OAc})_{2}$ catalyst and KOAC base in DMA, probably via a CMD mechanism (Scheme 8). ${ }^{[18]}$

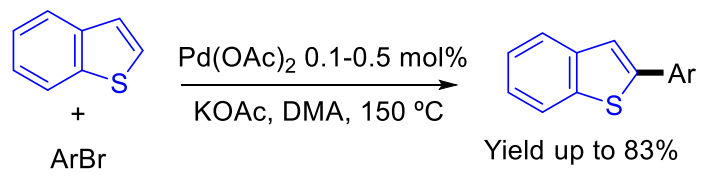

Scheme 8. Procedure for the C2-ary lations of benzothiophenes

However, some procedures promoting the regioselective $\beta$ arylations of benzothiophenes, have also been reported (Scheme 9). Studer and Itami applied their procedure phenylboronic acid as aryl source under Pd/TEMPO catalysis for the $\beta$-arylations of benzothiophene (Scheme 9, a). ${ }^{[19]}$ Then, in 2013, Bach and Schnapperelle found that $\mathrm{Pd}(\mathrm{TFA})_{2}$ catalyst in trifluoroacetic acid, in the presence of $\mathrm{Ag}_{2} \mathrm{O}$, cesium trifluoroacetate, benzoquinone, with phenylboronic acid as the aryl source also promoted the $\beta$-arylation of benzothiophene (Scheme 9, b). ${ }^{[20]}$ Our group also described a procedure for the Pd-catalyzed direct $\beta$-arylation of benzothiophenes (Scheme 9, c).$^{[17 a, 17 c]}$ Using again benzenesulfonyl chlorides as the aryl source, $\mathrm{PdCl}_{2}(\mathrm{MeCN})_{2}$ catalyst in the presence of $\mathrm{Li}_{2} \mathrm{CO}_{3}$ as base using 1,4-dioxane or diethyl carbonate as the solvent, the $\beta$-arylated benzothiophenes were obtained in high regioselectivities and good yields. In several cases, 10\% Pd/C catalyst has also proven to be an effective catalyst for these desulfitative couplings. ${ }^{[17 d]}$ Moreover, our conditions tolerated a wide scope of functional groups on the benzenesulfonyl chloride such as methoxy, cyano, chloro or bromo. a)<smiles></smiles>

b)<smiles>c1ccc2sccc2c1</smiles>
$\mathrm{PhB}(\mathrm{OH})_{2}$

c)<smiles></smiles>

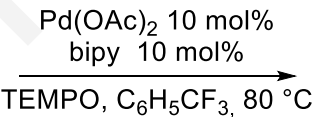<smiles>O=c1scc(-c2ccccc2)c2ccccc12</smiles>

Ratio C2:C3 1:99<smiles>O=S(=O)(O)c1ccccc1-c1csc2ccccc12</smiles>

$89 \%$ $25{ }^{\circ} \mathrm{C}$

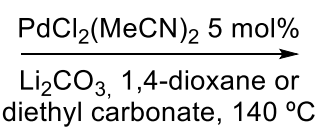

Yield up to $88 \%$

Scheme 9. Selected examples of C3-ary lations of benzothiophenes.

\subsection{Regiodivergent arylations of selenophenes}

Schneider et al. reported in 2014 , that the Pd-catalyzed direct arylation of selenophene occurs regioselectively at C2-position ( $\alpha$-arylation) in the presence of aryl halides and $\mathrm{K}_{2} \mathrm{CO}_{3}$ associated to $\mathrm{PivOH}$ as base (Scheme 10, a). This regiose lectivity probably arises from CMD mechanis $m^{[21]}$ Then, in 2017 our group found that us ing benzenesulfonyl chlorides as the aryl source instead of aryl halides, Pd-catalyzed desulfitative arylation of selenophenes occurs at C3- or C4-positions ( $\beta$ arylation) instead of C2-position (Scheme 10, b). ${ }^{[22 a]}$ The C3- or C4-arylated selenophenes were regiospecifically obtained using $10 \mathrm{~mol} \% \mathrm{Pd}(\mathrm{OAc})_{2}$ catalyst and 3 equiv. of $\mathrm{Li}_{2} \mathrm{CO}_{3}$ in 1,4dioxane. Interestingly, good yields were also obtained $w$ ith benzenesulfonyl chlorides containing halo-substituents including bromo and iodo. In addition, 2-bromo-4-arylselenophenes were regioselectively obtained from 2-bromoselenophene. In the course of these reactions, no $\mathrm{C}-\mathrm{Br}$ bond cleavage was observed. 
pivalate in DMA which promotes the $\alpha$-arylations, and so far this tool is effective only for (benzo)thiophenes and selenophenes.

\section{Blocking group}

a)<smiles>C1=C[Se]CC1</smiles>

$\mathrm{ArBr}$ or $\mathrm{Arl}$

b)

\begin{tabular}{|c|c|c|}
\hline & $\mathrm{Pd}(\mathrm{OAc})_{2} 10 \mathrm{~mol} \%$ & \\
\hline $\mathrm{rSO}_{2} \mathrm{Cl}$ & 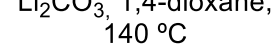 & Yield up to $78 \%$ \\
\hline
\end{tabular}

Scheme 10. Selected examples of regiodiv ergent ary lations of selenophenes.

We recently applied this methodology to the synthes is of planar $\pi$-extended selenium containing molecules. ${ }^{[22 b]}$ Combinations of Pd-catalyzed C-H bond arylations of 3-(2bromophenyl)selenophene $w$ ith either aryl bromides or benzenesulfonyl chlorides follow ed by intramolecular $\mathrm{C}-\mathrm{H}$ bond arylations allowed the extension of the selenophene-containing aromatic skeleton at the $[b]-$, or $[c]$-junctions to give either phenanthro $[b]$ selenophenes (Scheme 11, a), or phenanthro[c]selenophenes (Scheme 11, b).

a)
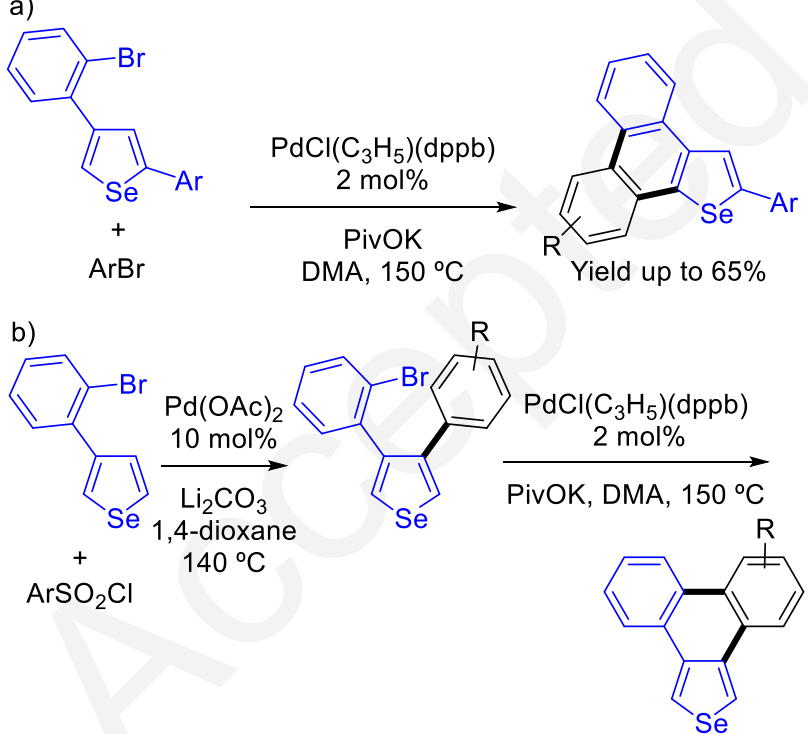

Yield up to $65 \%$

Scheme 11. Application to the synthesis of $\pi$-extended selenium containing molecules.

In summary, the use of some alternative aryl sources to aryl halides for the arylation of specific heteroarenes allow s to modify the regioselectivity of the arylation in favor of $\beta$-arylation. How ever, for such reactions higher catalyst loadings had to be employed than for the reactions with the system acetate or
The use of removable or synthetically useful blocking groups on substrates is an effective strategy for modifying the arylation site of (hetero)arenes. The introduction of chloride substituents as blocking groups on various heteroarenes in order to arylate specific positions has been described in 2010 by Fagnou et al. For example, through the introduction of a chloride substituents at C2-position of 3-hexylthiophene, the regioselectivity of the Pdcatalyzed direct arylation was diverted to produce alternative C5-arylated thiophenes. ${ }^{[23]}$ The use of blocking groups to obtain alternative regio isomers is not very attractive in many cases, as it may be required to introduce and then to remove such groups adding two steps to the synthesis scheme. However, this methodology may be synthetically useful in very specific cases, such as when the blocking group is readily present in commercial compounds, when it is easily eliminated during the coupling reaction, or $w$ hen it is useful in the next steps to access the final target.

\subsection{Esters substituents}

Esters are particularly interesting blocking groups because they are present on many commercial compounds and their removal of heteroarenes is often very easy. For example, we have reported the regiodivergent arylation of a thiophene substituted at C3- and C4-positions by two different functions using ester as blocking group at C2-position (Scheme 12). ${ }^{[24]}$ From 3-amino-4methylthiophene the direct arylation with both electron-deficient and electron-rich aryl bromides afforded regioselectively the C2arylated products in good yields (Scheme 12, a). Conversely, the coupling of bromobenzenes with methyl 3-amino-4methylthiophene-2-carboxylate gave the C5-arylated thiophenes (Scheme 12, b). The simple treatment of such 5-arylthiophenes by $\mathrm{KOH}$ in $\mathrm{EtOH} / \mathrm{H}_{2} \mathrm{O}$ gave the decarboxylated thiophenes. It should be mentioned that both thiophene substrates are commercially available.

a)

a) $\mathrm{H}_{2} \mathrm{~N}$<smiles>Cc1cscc1N</smiles>

$\mathrm{PdCl}\left(\mathrm{C}_{3} \mathrm{H}_{5}\right)(\mathrm{dppb}) 2 \mathrm{~mol} \%$ KOAC, DMA, $150{ }^{\circ} \mathrm{C}$<smiles>Cc1csc(Br)c1N</smiles>
$+$

Yield up to $80 \%$

b)

$\mathrm{ArBr}$

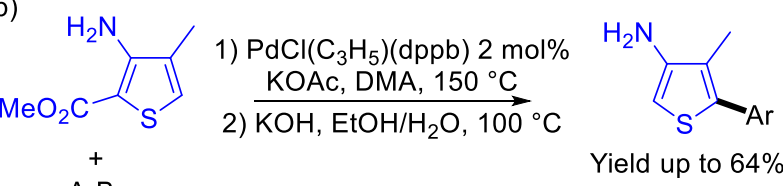

Scheme 12. Regiodiv ergent ary lations of thiophene deriv atives using an ester as blocking group.

In the course of the Pd-catalyzed arylation of 3-substituted thiophenes, position $\mathrm{C} 2$ is generally the most reactive. For example, the arylation of 3-methylthiophene in the presence of 
$\mathrm{Pd}(\mathrm{OAc})_{2} / \mathrm{dppb}$ catalyst affords the C2-arylated thiophenes in $82-87 \%$ regioselectivity (Scheme $13, a) .{ }^{[25]}$

Our group also examined the potential of esters as blocking groups at the C2-position of a range of 3-substituted thiophenes in order to control the regioselectivity for the direct arylation at C5-position (Scheme 13, b). ${ }^{[26]}$ The reactions performed at 100$140^{\circ} \mathrm{C}$ during 1-3 $\mathrm{h}$ proceeded nicely providing the C5-arylated thiophenes in good yields. Such C5-arylations can be follow ed by easy decarboxylation. We also observed that at $130-140{ }^{\circ} \mathrm{C}$, a slow decarboxylation reaction of some of the arylated estersubstituted thiophenes occurs. It $w$ as therefore possible to perform both catalytic C5-arylation and decarboxylation in one pot using a slightly higher reaction temperature and a longer time $(24-48 \mathrm{~h})$ (Scheme 13, c).

a)

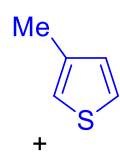

$\mathrm{ArBr}$
$\frac{\mathrm{Pd}(\mathrm{OAc})_{2} / \mathrm{dppb} 10 \mathrm{~mol} \%}{\mathrm{DMA}, \mathrm{KOAc}, 130{ }^{\circ} \mathrm{C}}$

Regioselectivity $82-87 \%$

b)<smiles>[R]c1ccsc1C(=O)OC</smiles>

$\mathrm{PdCl}\left(\mathrm{C}_{3} \mathrm{H}_{5}\right)(\mathrm{dppb}) 2 \mathrm{~mol} \%$ $1-3 \mathrm{~h}$

c)<smiles>[R]c1ccsc1C(=O)OC</smiles>

$\underset{\text { DMA, KOAC, } 130-140{ }^{\circ} \mathrm{C}}{\mathrm{PdCl}\left(\mathrm{C}_{3} \mathrm{H}_{5}\right)(\mathrm{dppb}) 2 \mathrm{~mol} \%}$ $24-48 \mathrm{~h}$
Yield up to $69 \%$<smiles>Cc1ccsc1[Te]</smiles>

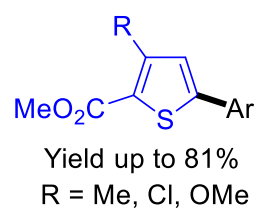

$\mathrm{R}=\mathrm{Me}, \mathrm{Cl}, \mathrm{OMe}$

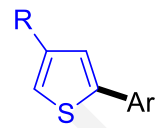

Yield up to $67 \%$ $\mathrm{R}=\mathrm{Cl}, \mathrm{OMe}$
Scheme 13. Regiodivergent ary lations of thiophene deriv atives using an ester as blocking group.

\subsection{Formyl and halo substituents}

The Pd-catalyzed direct arylation of pyrazoles is quite challenging due to the lack of regioselectivity of these coupling reactions. In 2009, Sames et al. determined the regioselectivity of such arylations, and their results indicated a higher reactivity at the C5-position relative to the C4-position and a very low reactivity at the C3-position. ${ }^{[27]}$ In most cases, they obtained mixtures of C4-, C5-arylated, and C4,C5-diarylated pyrazoles. In order to obtain regioselective C5-arylations, some groups introduced removable substituents at the C4-position of pyrazoles such as a chloro. ${ }^{[28]}$

Our group studied the potential of a formyl substituent as blocking group at the C4-position of pyrazoles. This blocking group is very appealing as a wide variety of 4-formylpyrazoles can be easily prepared from hydraz ine derivatives, ketones and DMF, and as the formyl group removal of 4-formy lpyrazoles using a palladium catalyst is a straightforw ard reaction. Indeed, we observed that 4-formylpyrazoles underwent Pd-catalyzed direct arylation reaction to provide regioselectively the 5-arylsubstituted pyrazoles (Scheme 14, a). The reaction proceeded in moderate to high yields using $2 \mathrm{~mol} \%$ of $\mathrm{Pd}(\mathrm{OAc})_{2}$ catalyst. $^{[29]}$
We also employed bromo- and iodo-substituents as blocking groups at C4-position of pyrazoles (Scheme 14, b and c). ${ }^{[30]}$ These C4-halosubstituted $\mathrm{N}$-protected pyrazole derivatives were regioselectively arylated at the C5-position using aryl bromides as the aryl source. The reaction $w$ as found to be highly chemoselective as the $\mathrm{C}-\mathrm{Br}$ or $\mathrm{C}-\mathrm{I}$ bonds on the pyrazole ring were not involved during the $\mathrm{C}-\mathrm{H}$ bond arylation process. These reactions proceeded in moderate to very high yields with electron-deficient aryl bromides or heteroaryl bromides. In addition, we also show ed that the bromo- or iodo-substituents of the arylated pyrazoles could either be employed for the preparation of $\mathrm{C} 4, \mathrm{C} 5$-diarylated pyrazoles, or a selective debromination or deiodination could be performed to afford the halogen-free 5-arylated pyrazole.

a)

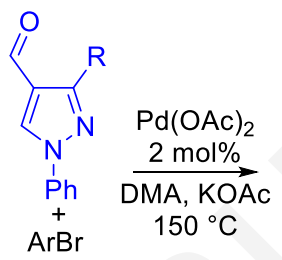

$\mathrm{R}=\mathrm{H}, \mathrm{Me}, \mathrm{Ph}$

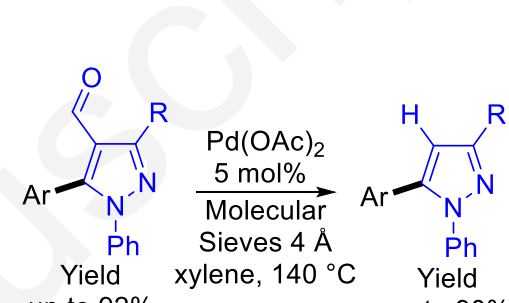

b)

$\mathrm{Br}$
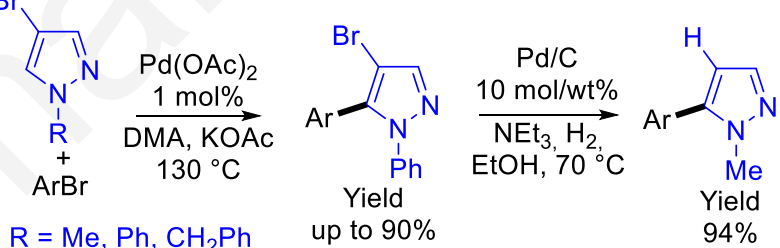

c)
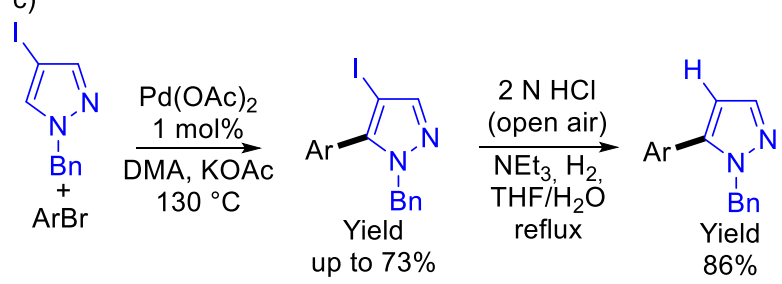

Scheme 14. C5-ary lations of py razoles using formyl or halogen substituents as blocking groups.

In order to obtain regioselectively $\mathrm{C} 4$-arylated pyrazoles, w e also studied the potential of an ester substituent as a temporary C5 blocking group. ${ }^{[31]}$ However, the C4-arylation of ethyl 2,5dimethylpyrazole-3-carboxylate proceeded in low yield. Then we turned our attention to the use of a chloro blocking group at the C5-position of pyrazole. In the presence of only 0.1-0.5 $\mathrm{mol} \% \mathrm{Pd}(\mathrm{OAc})_{2}$ catalyst, the 5-chloropyrazoles led to high yields in the desired C4-arylated pyrazoles (Scheme 15). ${ }^{[32]}$ Moreover, the dechlorination of these 4-aryl-5-chloropyrazoles proceeded nicely using $\mathrm{Pd} / \mathrm{C}$ catalyst. 


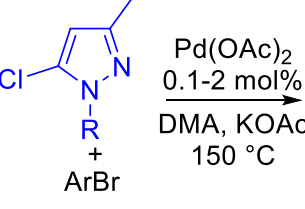

$\mathrm{R}=\mathrm{Me}, \mathrm{Ph}$
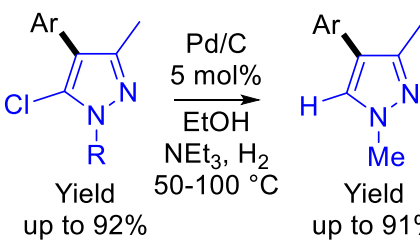

up to $91 \%$
Scheme 15. C4-ary lations of py razoles using a chloro substituent as blocking group.

\subsection{Protection via cyclometalation}

Aryl-substituted nitrogen-based compounds containing heterocycles, such as aryl-thienylpyridines have attracted increased interest due to their coordination properties making them important building blocks for the preparation of optoelectronic devices. How ever, the arylation of 2-pyridylthiophene at the C5-position of thienyl ring is quite challenging due to the coordination properties of the pyridine unit.

For example, Studer et al. reported in 2008 the oxidative coupling of 2-pyridylthiophene with arylboronic acids using $\mathrm{Pd}(\mathrm{OAc})_{2} / \mathrm{P}\left[p-\left(\mathrm{CF}_{3}\right) \mathrm{C}_{6} \mathrm{H}_{4}\right]_{3}$ as catalytic system and TEMPO as a stoichiometric oxidant (Scheme 16, a). ${ }^{[33)}$ In the course of this reaction, the 2-pyridyl unit acts as a directing group to mediate the arylation regioselectively at the C3-position of the thiophene ring.

Our group studied the Pd-catalyzed direct coupling of 2thienylpyridine using aryl bromides instead of arylboronic acids (Scheme 16, b) ${ }^{[34]}$ The results show that the reaction is not regioselective, as both the $\mathrm{C} 3$ - and $\mathrm{C} 5$-positions of the thienyl ring were arylated, and these two regio isomers were formed in an almost equimolar mixture, whatever the reaction conditions employed. The formation of the C3-arylated product likely arises from the coordination of the nitrogen atom of the pyridine ring to the palladium center; whereas, C5-arylation probably proceed via a concerted metallation deprotonation mechanism.

a)<smiles>c1ccc(-c2cccs2)nc1</smiles>

$\operatorname{ArB}(\mathrm{OH})_{2}$

b)

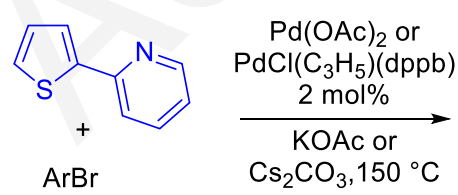

$\underset{\mathrm{TEMPO}, \mathrm{AcOH}}{\mathrm{Pd}(\mathrm{OAc})_{2} 10 \mathrm{~mol} \%}$ $\mathrm{KF}, 50^{\circ} \mathrm{C}$ $\mathrm{Cs}_{2} \mathrm{CO}_{3}, 150{ }^{\circ} \mathrm{C}$

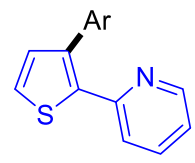

Yield up to $46 \%$

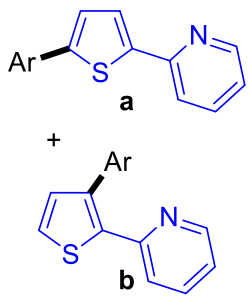

Yield in a up to $25 \%$ Ratio a:b 6:5
Scheme 16. Regioselectiv ity of the ary lations of 2-py ridylthiophene.
In order to inhibit the pyridine ring nitrogen atom coordination mechanis m, we performed the direct arylation of thienylpyridine ligands on bis- or tris-cyclometallated iridium complexes (Scheme 17). ${ }^{[35]}$ We found that the iridium-coordinated 2thiophen-2-ylpyridines could de directly arylated with aryl bromides regioselectively at the thienyl C5-position using 5 $\mathrm{mol} \% \mathrm{Pd}(\mathrm{OAc})_{2}$ catalyst. Since our goal for the arylation of 2thiophen-2-ylpyridines $w$ as to prepare ligands for the synthesis of cyclometallated iridium complexes, the use of iridium to block the C3-position of the thienyl ring is very practical. This latestage functionalization methodology opens new simple routes to a variety Ir complexes in only one step.

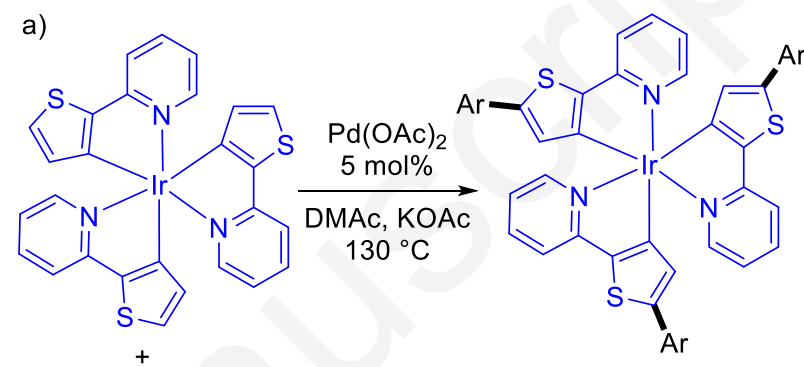

$\mathrm{ArBr}$

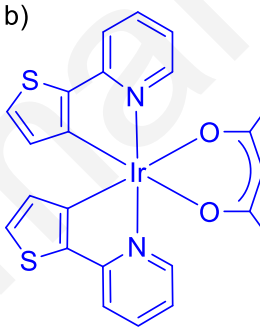

$\mathrm{ArBr}$
Yield up to $63 \%$

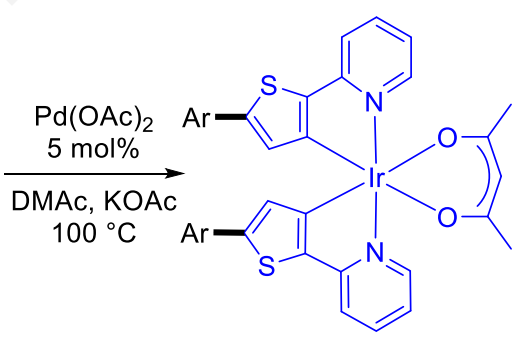

Yield up to $85 \%$
Scheme 17. C5-Ary lations of metallated 2-py ridy Ithiophene.

\section{Steric hindrance}

As explained in the scheme 13, in most cases, 3-substituted thiophenes such as 3-alkylthiophene or 3-cyanothiophene are arylated at their C2-position. ${ }^{[25]}$ How ever, the regioselectivity of the arylation of 3-substituted thiophenes is strongly influenced by the steric hindrance of both coupling partners. For example from 3-acetylthiophene and 9-bromoanthracene, the C5-arylated thiophene $w$ as obtained in $90 \%$ regioselectivity. ${ }^{[1,25]}$ Therefore, by using specific functional groups we expected to be able to obtain regiodivergent arylations.

Both 3-formy lthiophene and 3-for mylthiophene diethylacetal are commercially available at an affordable cost. In 2010, our group studied the regioselectivity of the arylation of these two thiophene derivatives, as we expected to observe a significant change in the regioselectivity of the arylation with these two substrates. ${ }^{[36]}$ Indeed, we observed that the arylation of 3 formylthiophene with aryl bromides occurs mainly at the C2position (regioselectivities 76-86\%) (Scheme 18, a). Conversely, with more congested 3-formylthiophene diethylacetal, the arylation occurred mainly at the C5-position (regioselectivities $64-88 \%$ ) (Scheme 18, b). Treatment of the 5-arylated 3- 
formylthiophene diethylacetals by $\mathrm{HCl}$ gives the corresponding C5-arylated 3-formylthiophenes.

a)<smiles>O=Cc1ccsc1</smiles>
$\mathrm{Pd}(\mathrm{OAc})_{2} 0.1 \mathrm{~mol} \%$
$\mathrm{dppb} 0.1 \mathrm{~mol} \%$
$S$

$\mathrm{ArBr}$

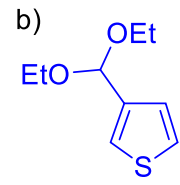

1) $\mathrm{Pd}(\mathrm{OAc})_{2} 0.1 \mathrm{~mol} \%$ dppb $0.1 \mathrm{~mol} \%$ KOAC, DMA, $150^{\circ} \mathrm{C}$ 2) $\mathrm{HCl}, \mathrm{THF}, 25^{\circ} \mathrm{C}$

$\mathrm{ArB}$<smiles>O=Cc1ccsc1Br</smiles>

Regioselectivity up to $86 \%$ Yield up to $61 \%$

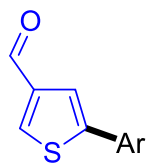

Regioselectivity up to $87 \%$ Yield up to $62 \%$
Scheme 18. Regioselectivity of the anylations of 3 -formylthiophene and 3formy lthiophene diethy lacetal.

The use of congested 2-bromo-1,3-dichlorobenzene as the coupling partner also allow ed to control the regioselectivity of the arylation of 3-substituted thiophene derivatives in favor of the C5-position. ${ }^{[37]}$ For example, the coupling of 2-bromo-1,3dichlorobenzene $w$ ith thiophenes bearing chloro, acetyl or methyl at C3-position afforded regioselectively in all cases the C5-arylated thiophenes (Scheme 19). How ever, we didn't succeed to remove the two chloro substituents of the benzene unit after the coupling reaction.

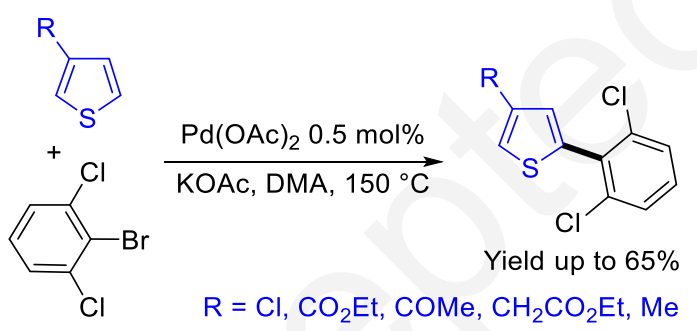

Scheme 19. Regioselectivity of the anylations of 3-substituted thiophene with 2-bromo-1,3-dichlorobenzene.

\section{Nature of the metal of catalysts}

One of the most obvious method to control the site-selectivity of the arylation of (hetero)arenes is the use of different metals as catalysts. Pd-catalysis is very effective for the arylation of heteroarenes and polyfluorobenzenes. By contrast, the Rucatalyzed direct arylations mostly relies on the coordination of the nitrogen atom of pyridines, diazines or $\mathrm{N}$-containing 5membered ring heteroarenes. Therefore, substrates containing these two types of units may lead to regiodivergent arylations. In our group, we studied the reactivity of such substrates in three different cases.

\subsection{Arylation of 2-(difluorophenyl)pyridines and quinolines}

In 2019, we reported the regiodivergent $\mathrm{C}-\mathrm{H}$ bond arylation of polyfluorinated 2-arylpyridines and 2-arylquinolines (Scheme 19). ${ }^{[38 a]}$ The use of a palladium catalyst promoted the functionalization of the $\mathrm{C}-\mathrm{H}$ bond of the aryl flanked by two fluorine atoms which is the most acidic position (Scheme 20, a). The best results were obtained with $\mathrm{PdCl}\left(\mathrm{C}_{3} \mathrm{H}_{5}\right)(\mathrm{dppb})$ catalyst. The use of this diphosphine palladium catalyst, might inhibit the formation of the regioisomer arising from nitrogen atom coordination, by preventing the coordination of the pyridine unit to palladium. With this catalyst, the regioselectivity was greatly improved to a $92: 8$ ratio (vs $76: 24 \mathrm{w}$ ith $\mathrm{Pd}(\mathrm{OAc})_{2}$ catalyst). The base which plays a critical role in CMD mechanis $m$ has an important influence on the reactions yields. Using very soluble base, KOPiv, full conversions of the aryl bromides were observed with good yields. Conversely, a $\mathrm{Ru}$ (II) complex promoted the $\mathrm{C}-\mathrm{H}$ bond arylation at the ortho-position of the aryl unit of 2-arylpyridines or 2-arylquinolines via coordination of the nitrogen atom to ruthenium (Scheme 20, b). Using $5 \mathrm{~mol} \%$ of $\left[\mathrm{Ru}(p \text {-cymeme }) \mathrm{Cl}_{2}\right]_{2}$ associated to $\mathrm{KOAc}$, the arylation proceeded in $>95: 5$ selectivity, and in good yields.

In 2020, we applied this strategy to the arylation of the phenyl ring of 2-(2,4-difluorophenyl)-5-(trifluoromethyl)pyridine and 2(3,5-difluorophenyl)-5-(trifluoromethy l)pyridine for the access to two families of Ir(III) complexes, charge-neutral and cationic species which show bright photoluminescence. The reaction was regioselective since only the C3- or C4-positions of the difluorinated phenyl rings were readily functionalized (Scheme 20, a and c). a)
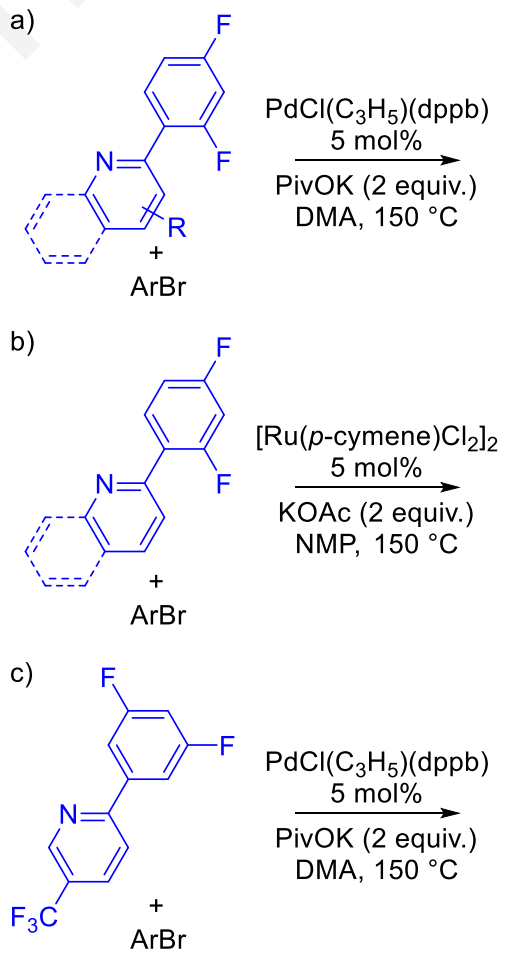

$\mathrm{PdCl}\left(\mathrm{C}_{3} \mathrm{H}_{5}\right)(\mathrm{dppb})$ $\underset{\text { PivOK }(2 \text { equiv. })}{\stackrel{5 \text { mol\% }}{\longrightarrow}}$ DMA, $150^{\circ} \mathrm{C}$<smiles>[R]c1cc2ccccc2nc1-c1ccc(F)c([18OH])c1F</smiles>

Scheme 20. Regiodivergent Pd- or Ru-catalyzed direct arylations of 2(dif luoropheny I)py ridines and quinolines. 


\subsection{Arylation of Diflufenican}

Diflufenican, which is an herbicide, contains a 1,3difluorobenzene ring and a pyridine ring (Scheme 21). Therefore, it also represents a very interesting molecule in terms of site-selectivity for the metal-catalyzed $\mathrm{C}-\mathrm{H}$ bond functionalization. When appropriate reaction conditions are employed, the Pd- and Ru-catalyzed $\mathrm{C}-\mathrm{H}$ bond functionalization of Diflufenican protected as a tertiary amide afforded two different families of compounds. ${ }^{[39]}$ With a Pd-catalyst, Diflufenican $\mathrm{w}$ as regioselectively arylated at the $\mathrm{C}-\mathrm{H}$ position flanked by tw o fluorine atoms (most acidic position); w hereas, no arylation of the trifluoromethylbenzene ring $w$ as detected under these reaction conditions (Scheme 21, a). In sharp contrast, with a Ru-catalyst, the arylation regioselectively occurred at the less hindered ortho-position of the ether function of the trifluoromethylbenzene ring via the coordination of the pyridine ring to ruthenium (Scheme 21, b). With these tw o procedures, the arylated Diflufenican derivatives were obtained in moderate to good yields.
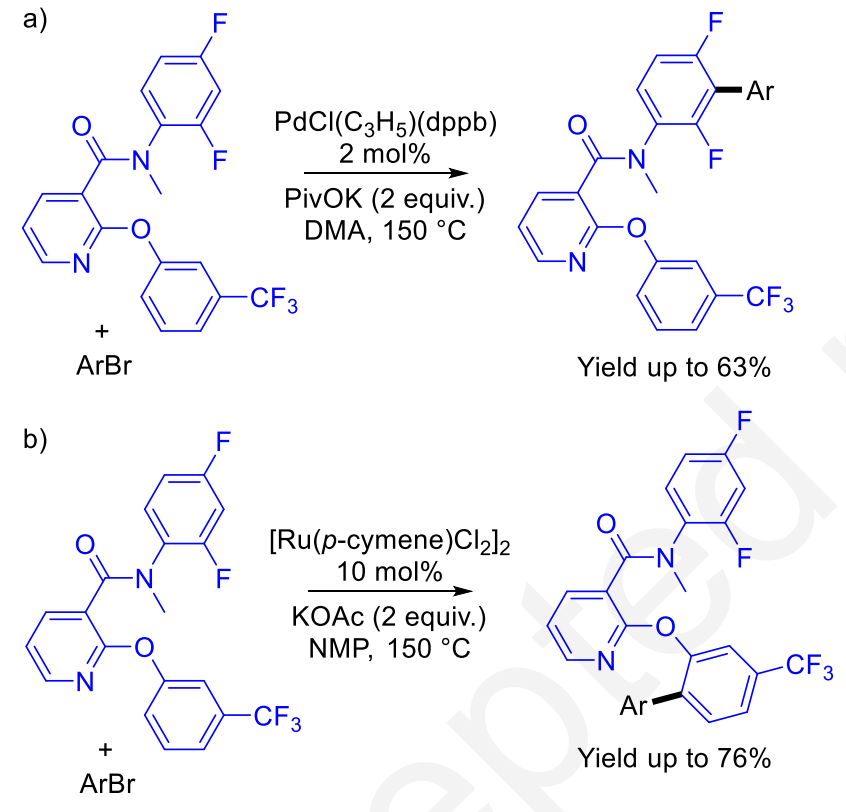

Yield up to $63 \%$

Scheme 21. Regiodiv ergent Pd- or Ru-catalyzed direct arylations of Dif luf enican.

\subsection{Arylation of 2-aryloxazoles}

We also studied the reactivity of 2-aryloxazoles using $\mathrm{Pd}$ and $\mathrm{Ru}$ catalysts. $^{[40]}$ From 2-aryloxazoles and a set of electron-rich or poor aryl bromides, in the presence of $\mathrm{Pd}(\mathrm{OAc})_{2}$ catalyst, the 2,5-diaryloxazoles were obtained $w$ ith complete regioselectivity and high yields (Scheme 22, a). Conversely, the Ru-catalyzed direct arylation of 2-aryloxazoles occurred at the aryl unit via coordination of the nitrogen atom of oxazole to ruthenium (Scheme 22, b). For these reactions, [Ru(p-cymene) $\left.\mathrm{Cl}_{2}\right]_{2}$ was employed as the catalyst and KOPiv as the base. ${ }^{[41]}$

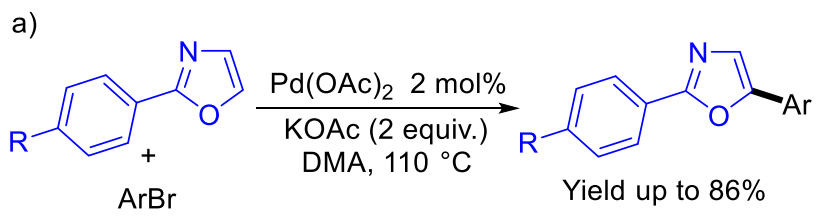

b)<smiles>[R]c1cccc(-c2ncco2)c1</smiles>
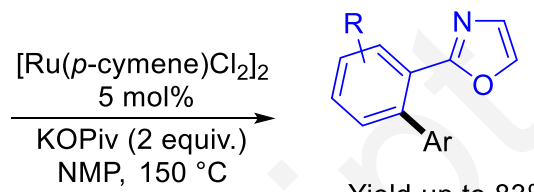

Yield up to $83 \%$

Scheme 22. Regiodivergent Pd- or Ru-catalyzed direct arylations of 2 ary loxazoles.

\section{Conclusion}

In summary, in several cases, the metal-catalyzed $\mathrm{C}-\mathrm{H}$ bond functionalization for the arylation of (hetero)arenes is not limited to only one "most reactive" $\mathrm{C}-\mathrm{H}$ bond of the substrates. The use of several tools which include the use of various aryl sources, the modification of some of the reaction conditions such as the base and solvent, the introduction of blocking groups, the use of directing functional groups such as amides, the nature of the metal catalyst allowed to modify the site selectivity for several substrates resulting in regiodivergent arylations. The steric hindrance of the substrates can also be employed to control the regioselectivity of the reactions. Therefore, metal-catalyzed direct arylation now represents a powerful method to access arylated (hetero) aromatics. How ever, many challenges remain, as in some cases, mixtures of regioisomers and/or low yields were obtained. In several cases, more efficient catalysts allowing low er catalyst loadings need to be discovered in order to provide more economically attractive procedures. Concerning the different mechanis ms involved in changing regioselectivity, a large number of questions remain unanswered. Determining more clearly the mechanistic reasons leading to the different observed regioselectivities would certainly improve further the efficiency and scope of such reactions. Moreover, in the near future, there are no doubts that new tools will be discovered allowing to functionalize more and more $\mathrm{C}-\mathrm{H}$ bonds of several (hetero)arenes making this reaction an unavoidable synthesis method in the preparation of poly(hetero)aryls.

\section{Acknowledgements}

We thank China Scholarship Council for providing financial support to H.-Y.H., the Algeria "Ministry of Higher Education and Scientific Research" for a fellowship to A.B., and the ANR (ANR16-CE07-0001) for a grant to X.S.

Keyw ords: regiodivergence $\cdot$ arylation $\cdot \mathrm{C}-\mathrm{H}$ bond functionalization $\cdot$ catalysis $\cdot$ palladium

[1] For rev iews on C-H bond functionalization: a) T. Satoh, M. Miura, Chem Lett., 2007, 36, 200-205; b) L Ackermann, R. Vicente, A. R. Kapdi, 
Angew. Chem. Int. Ed., 2009, 48, 9792-9826; c) F. Bellina, R. Rossi, Tetrahedron, 2009, 65, 10269-10310; d) P. B. Arockiam, C. Bruneau, P. H. Dixneuf, Chem Rev. 2012, 112, 5879-5918; e) R. Rossi, F. Bellina, M. Lessi, C. Manzini, Adv. Synth. Catal., 2014, 356, 17-117; f) C. B. Bheeter, L. Chen, J.-F. Soulé, H. Doucet, Cat. Sci. Technol. 2016, 6 , 2005-2049; g) L. Theveau, C. Schneider, C. Fruit, C. Hoarau, ChemCatChem 2016, 8, 3183-3194; h) L Ping, D. S. Chung, J Bouffard, S.-g. Lee, Chem Soc. Rev. 2017, 46, 4299-4328; i) T. Gensch, M. J. James, T. Dalton, F. Glorius, Angew. Chem Int. Ed 2018, 57, 2296-2306; j) K. Hirano, M. Miura, Chem Sci. 2018, 9, 22-32; k) P. Gandeepan, T. Mueller, D. Zell, G. Cera, S. Warratz, L. Ackermann, Chem Rev. 2019, 119, 2192-2452; I) S. Mao, H. Li, X. Shi, J.-F. Soulé, H. Doucet, ChemCatChem 2019, 11, 269-286; m) W Hagui, H. Doucet, J.-F. Soulé, Chem 2019, 5, 2006-2078; n) S. Rej, Y. Ano, N. Chatani, Chem Rev. 2020, 120, 1788-1887.

[2] For early results on Pd-catalyzed $\mathrm{C}-\mathrm{H}$ bond functionalization of heteroarenes: a) N. Nakamura, Y. Tajima, K. Sakai, Heterocycles, 1982 17, 235-245; b) Y. Akita, A. Inoue, K. Yamamoto, A. Ohta, T. Kurihara, M. Shimizu, Heterocycles 1985, 23, 2327-2333; c) A. Ohta, Y. Akita, T. Ohkuwa, M. Chiba, R. Fukunaga, A. My af uji, T. Nakata, N. Tani, Y. Aoy agi, Heterocycles, 1990, 31, 1951-1958; d) Y. Aoy agi, A. Inoue, I. Koizumi, R. Hashimoto, A. Miy af uji, J. Kunoh, R. Honma, Y. Akita, A. Ohta, Heterocycles 1992, 33, 257-272.

[3] For early results on $\mathrm{Ru}$ - or Pd-cataly zed $\mathrm{C}-\mathrm{H}$ bond functionalization of 2-ary lpy ridines, 2-ary lazoles or fluorobenzenes: a) S. Oi, S. Fukita, N. Hirata, N. Watanuki, S. My ano, Y. Inoue, Org. Lett. 2001, 3, 2579 2581 ; b) S. Oi, H. Sasamoto, R. Funay ama, Y. Inoue, Chem Lett. 2008, 37, 994-995; c) M. Laf rance, C. N. Rowley, T. K. Woo, K. Fagnou, J. Am Chem Soc. 2006, 128, 8754-8756.

[4] R. S. Sánchez, F. A. Zhuravlev, J. Am Chem Soc. 2007, 129, 58245825.

[5] N. A. Strotman, H. R. Chobanian, Y. Guo, J. He, J. E. Wilson, Org. Lett 2010, 12, 3578-3581.

[6] a) S. I. Gorelsky, D. Lapointe, K. Fagnou, J. Org. Chem 2012, 77, 658668; b) S. I. Gorelsky, Coord. Chem Rev. 2013, 257, 153-164.

[7] X. Shi, J.-F. Soulé, H. Doucet, Adv. Synth. Catal. 2019, 361, 4748-4760.

[8] L. Zhao, C. Bruneau, H. Doucet, Chem Commun. 2013, 49, 5598-5600.

[9] F. Yang, Y. Wu, Z. Zhu, J. Zhang, Y. Li, Y. Tetrahedron 2008, 64, 67826787.

[10] F. Abdellaoui, C. Youssef, H. Ben Ammar, T. Roisnel, J.-F. Soulé, H. Doucet, ACS Catal. 2016, 6, 4248-4252.

[11] T. Okazawa, T. Satoh, M. Miura, M. Nomura, J. Am Chem. Soc. 2002, 124, 5286-5287.

[12] a) N. Laidaoui, J. Roger, A. Miloudi, D. El Abed, H. Doucet, Eur. J. Org. Chem. 2011, 4373-4385; b) K. Si Larbi, H. Y. Fu, N. Laidaoui, K Beydoun, A. Miloudi, D. El Abed, S. Djebbar, H. Doucet, ChemCatChem 2012, 4, 815-823.

[13] J. Roger, F. Požgan, H. Doucet, Green Chem 2009, 11, 425-432.

[14] S. Kirchberg, S. Tani, K. Ueda, J. Yamaguchi, A. Studer, K. Itami, Angew. Chem Int. Ed. 2011, 50, 2387-2391.

[15] K. Funaki, T. Sato, S. Oi, Org. Lett. 2012, 14, 6186-6189.

[16] a) D.-T. D. Tang, K. D. Collins, J. B. Ernst, F. Glorius, Angew. Chem Int. Ed. 2014, 53, 1809-1813; b) C. Colletto, S. Islam, F. JuliaHernandez, I. Larrosa, J. Am Chem Soc. 2016, 138, 1677-1683.

[17] a) K. Yuan, H. Doucet, Chem Sci. 2014, 5, 392-396; b) A. Skhiri, A. Beladhria, K. Yuan, J.-F. Soulé, R. Ben Salem, H. Doucet, Eur. J. Org. Chem. 2015, 4428-4436; c) A. Hfaiedh, K. Yuan, H. Ben Ammar, B. Ben Hassine, J.-F. Soulé, H. Doucet, ChemSus Chem 2015, 8, 17941804; d) S. Mao, X. Shi, Xinzhe; J.-F. Soulé, H. Doucet, Eur. J. Org Chem. 2020, 91-97; e) X. Zhao, E. Dimitrijevic, V. M. Dong, J. Am
Chem. Soc. 2009, 131, 3466-3467; f) W. Hagui, N. Besbes, E. Srasra, T. Roisnel, J.-F. Soulé, H. Doucet, Org. Lett. 2016, 18, 4182-4185.

[18] L. Zhao, C. Bruneau, H. Doucet, Tetrahedron 2013, 69, 7082-7089.

[19] S. Kirchberg, S. Tani, K. Ueda, J. Yamaguchi, A. Studer, K. Itami, Angew. Chem Int. Ed. 2011, 50, 2387-2391.

[20] I. Schnapperelle, T. Bach, ChemCatChem 2013, 5, 3232-3236.

[21] a) S. Tamba, R. Fujii, A. Mori, K. Hara, N. Koumura, Chem Lett. 2011 40, 922-924; b) D. S. Rampon, L. A. Wessjohann, P. H. Schneider, J. Org. Chem 2014, 79, 5987-5992.

[22] a) A. Skhiri, R. Ben Salem, J.-F. Soulé, H. Doucet, Chem Eur. J. 2017, 23, 2788-2791; b) X. Shi, S. Mao, T. Roisnel, J.-F. Soulé, H. Doucet, Org. Chem Front. 2019, 6, 2398-2403.

[23] B. Liégault, I. Petrov, S. I. Gorelsky, K. Fagnou, J. Org. Chem 2010, 75, 1047-1060.

[24] F. Derridj, K. S. Larbi, J. Roger, S. Djebbar, H. Doucet, Tetrahedron 2012, 68, 7463-7471.

[25] J. J. Dong, D. Roy, R. Jacob Roy, M. Ionita, H. Doucet, Synthesis 2011, 3530-3546.

[26] L. Chen, C. Bruneau, P. H. Dixneuf, H. Doucet, Green Chem 2012, 14 , 1111-1124.

[27] R. Goikhman, T. L. Jacques, D. Sames, J. Am Chem. Soc. 2009, 131, 3042-3048.

[28] C. Mateos, J. Mendiola, M. Carpintero, J. M. Minguez, Org. Lett. 2010 12, 4924-4927.

[29] I. Smari, C. Youssef, K. Yuan, A. Beladhria, H. Ben Ammar, B. Ben Hassine, H. Doucet, Eur. J. Org. Chem 2014, 1778-1786.

[30] a) M. Brahim, I. Smari, H. Ben Ammar, B. Ben Hassine, J. -F. Soulé, H. Doucet, Org. Chem Front. 2015, 2, 917-926; b) M. Brahim, H. Ben Ammar, J.-F. Soulé, H. Doucet, Tetrahedron 2016, 72, 4312-4320.

[31] Y. Fall, H. Doucet, M. Santelli, Synthesis 2010, 127-135.

[32] T. Yan, L. Chen, C. Bruneau, P. H. Dixneuf, H. Doucet, J. Org. Chem 2012, 77, 7659-7664

[33] S. Kirchberg, T. Vogler, A. Studer, Synlett 2008, 2841-2845.

[34) J. Laroche, K. Bey doun, V. Guerchais, H. Doucet, Catal. Sci. Technol. 2013, 3, 2072-2080.

[35] a) K. Bey doun, M. Zaarour, J. A. G. Williams, H. Doucet, V. Guerchais, Chem. Commun. 2012, 48, 1260-1262; b) K. Bey doun, M. Zaarour, J. A. G. Williams, T. Roisnel, V. Dorcet, A. Planchat, A. Boucekkine, D. Jacquemin, H. Doucet, V. Guerchais, Inorg. Chem 2013, 52, 1241612428.

[36] J. J. Dong, H. Doucet, Eur. J. Org. Chem 2010, 611-615.

[37] R. Jin, C. B. Bheeter, H. Doucet, Beilstein J. Org. Chem 2014, 10, 1239-1245.

[38] a) R. Boyaala, R. Touzani, T. Roisnel, V. Dorcet, E. Caytan, D. Jacquemin, J. Boixel, V. Guerchais, H. Doucet, J.-F. Soulé, ACS Catal. 2019, 9, 1320-1328; b) R. Boy aala, M. Peng, W.-S. Tai, R. Touzani, T. Roisnel, V. Dorcet, Y. Chi, V. Guerchais, H. Doucet, J.-F. Soulé, Inorg. Chem 2020, 59, 13898-13911.

[39] M. Elhadi Benhalouche, H. Li, A. Miloudi, A. Benzai, M. Cordier, J.-F. Soulé, H. Doucet, Eur. J. Org. Chem 2020, 4792-4795.

[40] X. Shi, J.-F. Soulé, H. Doucet, Adv. Synth. Catal. 2019, 361, 4748-4760.

[41] For other examples of Ru-cataly zed ary lations of 2-ary loxazoles, see ref $3 \mathrm{~b}$ and W. Li, P. B. Arockiam, C. Fischmeister, C. Bruneau, P. H. Dixneuf, Green Chem 2011, 13, 2315-2319. 


\section{Entry for the Table of Contents}

\section{PERSONAL ACCOUNT}

Over the past decade, several synthetic tools allowing the direct arylation of tw o different $\mathrm{C}-\mathrm{H}$ bonds of the same organic molecule - also called regiodivergent arylation - have been described. In this account, we summarize our results using the different tools that have allow ed us to arylate different positions of various (hetero)arenes, via the functionalization of $\mathrm{C}-\mathrm{H}$ bonds, using palladium or ruthenium catalysis.
Hai-Yun Huang, ${ }^{[a]}$ Amal Benzai, ${ }^{[a]}$ Xinzhe Shi, ${ }^{[a]}$ and Henri Doucet ${ }^{\star[a]}$

Page No. - Page No.

Effective tools for the metal-catalyzed regiodivergent direct arylations of (hetero)arenes

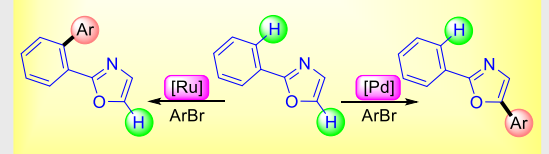

